\title{
Quality of Life of Nurses in Osijek
}

1 Tihana Batrnek

1 Mateo Gašpert

1 Josip Juraj Strossmayer University of Osijek Faculty of Medicine: University graduate study of Nursing, Osijek, Croatia

Article received: 02.01.2018.

Article accepted: 03.10.2018.

Author for correspondence:

Mateo Gašpert

Phone: + 385996945181

E-mail: m.gaspert8@gmail.com

DOI: $10.24141 / 2 / 2 / 2 / 2$

Keywords: quality of life, shift work, nurse

\section{Abstract}

Introduction. The nurse is the one who will be with patients, listen to them, talk to them, provide security, and focus their attention on them. The nurse is unique. The World Health Organisation defines quality of life as the perception of the role of the individual in the context of culture and values in which he lives and in relation to his goals, expectations, standards and concerns.

Aim. To examine the quality of life of nurses in the Clinical Hospital Center Osijek and Health center Osijek.

Study design. A cross-sectional study.

Methods. The study includes the total of 117 nurses, 64 of whom work in the Clinical Hospital Centre in Osijek and 53 are employed in primary health care. The World Health Organization Quality of Life Questionnaire is used in the study. Demographic characteristics are examined in the first part of the questionnaire, and in the second part of the questionnaire participants were asked questions that are related to the quality of their lifestyle.

Results. Nurses rated their quality of life as good $(45.3 \%)$, also, they are satisfied with their health (59.8\%). Respondents in the age group from 22 to 32 are most satisfied with the domain "Social relations" with the arithmetic mean of 63,06 and $p$ value 0.048. All three questions from the domain "Social relationship of nurses" had high arithmetic means which were over 3.60.

Conclusion. Quality of life of nurses is at a good level. Younger respondents have a better quality of life. Respondents are most satisfied with their own agility and meaning of their lives, while they are most dissatisfied with their financial situation and opportunities for recreation. 


\section{Introduction}

"The unique function of the nurse is to assist the individual, sick or well, in the performance of those activities contributing to health or its recovery (or to peaceful death) that he would perform unaided if he had the necessary strength, will or knowledge. And to do this in such a way as to help him gain independence as rapidly as possible" (1).

Each member of the medical team is bound to help the patient to regain independence, but a nurse is a person who spends most time with them while there is no necessary strength, will or knowledge. It is important to point out that a nurse has independence in nursing care and adequately takes care of the patient and that is why there is a chance to observe each patient and perceive their needs, notice potential problems and help the patient to solve them in order to have fast recovery. A nurse is more than a person who assists the patient in the recovery, it is their spokesman. A nurse realizes that the patient has difficulty expressing needs and feelings and, just like a mother, intercedes for them, speaks for them, because a nurse knows what the patient wants. Because they provide the necessary care, a nurse has the opportunity to advise the patient, encourage positive habits and warn about the bad ones. The nurse is the one who will be with them, listen to them, talk to them, provide security, and focus their attention on them. The nurse is unique.

\section{Definition of quality of life}

The World Health Organisation defines quality of life as the perception of the role of the individual in the context of culture and values in which he lives and in relation to his goals, expectations, standards and concerns (2). International Wellbeing Group defines quality of life as a multidimensional construct that comprises the standard of living, health, productivity, the possibility of achieving close contact, security, belonging to a community and a sense of security in the future (3).

\section{Quality of life indicators}

Quality of life includes both an objective and a subjective component. The subjective component of qual- ity of life includes seven areas: material well-being, emotional well-being, health, productivity, intimacy, safety and community. Objective indicators of quality of life are: income, availability of health services, the availability of different services, numeric indicators of employment and others. It has been shown that subjective well-being has a more important role in determining the overall welfare over objective indicators (4).

Vuletić (4) considers quality of life as well-being affected by objective indicators, a large proportion has a subjective perception and evaluation of physical, material, social and emotional well-being, personal development and purposeful activity. One of the important indicators of quality of life is health. Health is defined as "a state of complete physical, mental and social well-being and not merely the absence of disease or infirmity" (5).

The aim of the research study was to examine the quality of life of nurses in the Clinical Hospital Center Osijek and Health center Osijek.

\section{Methods}

This study was cross-sectional. The study was conducted during 2015 and included the total of 117 nurses, of which 64 respondents were from the Clinical Hospital Centre Osijek, and 53 of them worked at the primary health care at the Health center Osijek. The World Health Organization Quality of Life Questionnaire (WHOQOL - BREF (1998.)) was used in the study. It is a short version of the WHOQOL-100 questionnaire. WHOQOL-BREF consists of 26 questions. In each of these questions, respondents answered on Likert scale (1-5). There are four domains: physical health, psychological health, social relationship and environment (6).

In the Clinical Hospital Center Osijek research was conducted at 5 clinics: Department of Internal Medicine (20.3\%), Department of Psychiatry (4.7\%), Department of Pediatrics (20.3\%), Department of Surgery $(29.7 \%)$ and Department of Neurology (25\%). The total number of respondents was 112 females and 5 males. 
The average age of respondents was 40.56 years with a standard deviation of 11.73 years. The age range of respondents was from 22 to 64 .

The data set was subject to statistical anysis using SPSS (Version 16.0). Categorical data were presented in absolute and relative frequencies. Numerical data were described as mean and standard deviation. The connection of normally distributed numerical variables was evaluated by Pearson correlation coefficient r. All $p$ values are two-sided. The level of significance was set at alpha $<0.05$.

\section{Ethical Considerations}

Ethical permission was sought and gained for the study through the local Ethics Committee and the University Committee, copies of which have been retained for inspection.

\section{Results}

Of the total number of respondents, $29.9 \%$ of the respondents have no children, $19.7 \%$ of the respondents have one child, $44.4 \%$ of the respondents have two children, while $6 \%$ of the respondents have three children. $71 \%$ of the respondents live in urban areas, $29 \%$ in rural areas. Most of the repondents live in a house or a flat (76.1\%).

Of all respondents, 72 respondents or $61.6 \%$ have secondary education, 41 respondents (35\%) have a Bachelor of Science in Nursing, and 4 respondents (3.4\%) have a Master of Science in Nursing. Most of the respondents work in shifts (39\%), 12/24/12/48 type of work (33\%), other type of work (28\%).

Nurses rated their quality of life as good (45.3\%) and neither poor nor good (31.6\%). Also, they are satisfied with their health (59.8\%) (Table 1).

In the subscale "Physical health", nurses need a little $(40.2 \%)$ and a moderate amount of medical treatment to function in their daily life $(36.8 \%)$, followed by the lowest arithmetic mean of 1.88 . Most of the nurses think that they are very much able to get around (47\%) confirmed by the highest arithmetic mean of 4.15 . Also, most of them are satisfied with the ablility to perform their activities of daily living (48.7\%) and they are satisfied with their capacity for work (55.6\%) (Table 2).

The highest arihtmetic mean for the domain "Mental health of nurses" was 4.15 for the question about the meaning of their life. The lowest arihtmetic mean was 2.45 for the question about experiencing negative feelings (Table 3 ).

Results show that nurses are satisfied with their social relationships. All three questions about social relationship of nurses had high arithmetic means which were over 3.6 (Table 4).

\begin{tabular}{|c|c|c|c|c|c|}
\hline & & Number & $\begin{array}{c}\text { Percentage } \\
\text { (\%) }\end{array}$ & $\begin{array}{l}\text { Arithmetic } \\
\text { mean }\end{array}$ & $\begin{array}{l}\text { Standard } \\
\text { deviation }\end{array}$ \\
\hline \multirow{6}{*}{$\begin{array}{l}\text { How would you } \\
\text { rate your quality } \\
\text { of life? }\end{array}$} & Very poor & 2 & 1.7 & & \\
\hline & Poor & 4 & 3.4 & & \\
\hline & Neither poor nor good & 37 & 31.6 & & \\
\hline & Good & 53 & 45.3 & & \\
\hline & Very good & 21 & 17.9 & & \\
\hline & Total & 117 & 100 & 3.74 & 0.85 \\
\hline \multirow{6}{*}{$\begin{array}{l}\text { How satisfied } \\
\text { are you with } \\
\text { your health? }\end{array}$} & Very dissatisfied & 0 & 0.0 & & \\
\hline & Dissatisfied & 9 & 7.7 & & \\
\hline & Neither satisfied nor dissatisfied & 17 & 14.5 & & \\
\hline & Satisfied & 70 & 59.8 & & \\
\hline & Very satisfied & 21 & 17.9 & & \\
\hline & Total & 117 & 100 & 3.88 & 0.79 \\
\hline
\end{tabular}




\begin{tabular}{|c|c|c|c|c|c|}
\hline & & Number & $\begin{array}{l}\text { Percentage } \\
(\%)\end{array}$ & $\begin{array}{l}\text { Arithmetic } \\
\text { mean }\end{array}$ & $\begin{array}{l}\text { Standard } \\
\text { deviation }\end{array}$ \\
\hline \multirow{6}{*}{$\begin{array}{l}\text { To what extent do you feel that } \\
\text { physical pain prevents you from } \\
\text { doing what you need to do? }\end{array}$} & Not at all & 46 & 39.3 & & \\
\hline & A little & 34 & 29.1 & & \\
\hline & A moderate amount & 26 & 22.2 & & \\
\hline & Very much & 9 & 7.7 & & \\
\hline & An extreme amount & 2 & 1.7 & & \\
\hline & Total & 117 & 100 & 2.03 & 1.04 \\
\hline \multirow{7}{*}{$\begin{array}{c}\text { How much do you need any medical } \\
\text { treatment to function in your daily } \\
\text { life? }\end{array}$} & Not at all & 2 & 1.7 & & \\
\hline & A little & 47 & 40.2 & & \\
\hline & A moderate amount & 43 & 36.8 & & \\
\hline & Very much & 14 & 12 & & \\
\hline & An extreme amount & 10 & 8.5 & & \\
\hline & Not at all & 1 & 0.9 & & \\
\hline & Total & 117 & 100 & 1.88 & 1.00 \\
\hline \multirow{7}{*}{$\begin{array}{c}\text { Do you have enough energy for } \\
\text { everyday life? }\end{array}$} & No answer & 3 & 2.6 & & \\
\hline & Not at all & 1 & 0.9 & & \\
\hline & A little & 7 & 6 & & \\
\hline & Moderately & 39 & 33.3 & & \\
\hline & Mostly & 51 & 43.6 & & \\
\hline & Completely & 16 & 13.7 & & \\
\hline & Total & 117 & 100 & 3.56 & 1.00 \\
\hline \multirow{7}{*}{ How well are you able to get around? } & No answer & 2 & 1.7 & & \\
\hline & Very poor & 1 & 0.9 & & \\
\hline & Poor & 5 & 4.3 & & \\
\hline & Neither poor nor good & 16 & 13.7 & & \\
\hline & Good & 38 & 32.5 & & \\
\hline & Very good & 55 & 47 & & \\
\hline & Total & 117 & 100 & 4.15 & 1.06 \\
\hline \multirow{7}{*}{$\begin{array}{l}\text { How satisfied are you with your } \\
\text { sleep? }\end{array}$} & No answer & 2 & 1.7 & & \\
\hline & Very dissatisfied & 7 & 6 & & \\
\hline & Dissatisfied & 16 & 13.7 & & \\
\hline & Neither satisfied nor dissatisfied & 24 & 20.5 & & \\
\hline & Satisfied & 45 & 38.5 & & \\
\hline & Very satisfied & 23 & 19.7 & & \\
\hline & Total & 117 & 100 & 3.47 & 1.22 \\
\hline \multirow{7}{*}{$\begin{array}{l}\text { How satisfied are you with your } \\
\text { ability to perform your daily living } \\
\text { activities? }\end{array}$} & No answer & 2 & 1.7 & & \\
\hline & Very dissatisfied & 1 & 0.9 & & \\
\hline & Dissatisfied & 7 & 6 & & \\
\hline & Neither satisfied nor dissatisfied & 27 & 23.1 & & \\
\hline & Satisfied & 57 & 48.7 & & \\
\hline & Very satisfied & 23 & 19.7 & & \\
\hline & Total & 117 & 100 & 3.75 & 0.98 \\
\hline \multirow{7}{*}{$\begin{array}{c}\text { How satisfied are you with your } \\
\text { capacity for work? }\end{array}$} & No answer & 2 & 1.7 & & \\
\hline & Very dissatisfied & 0 & 0 & & \\
\hline & Dissatisfied & 3 & 2.6 & & \\
\hline & Neither satisfied nor dissatisfied & 16 & 13.7 & & \\
\hline & Satisfied & 65 & 55.6 & & \\
\hline & Very satisfied & 31 & 26.5 & & \\
\hline & Total & 117 & 100 & 4.01 & 0.89 \\
\hline
\end{tabular}


Table 3. Mental health of nurses

\begin{tabular}{|c|c|c|c|c|c|}
\hline & & Number & Percentage (\%) & $\begin{array}{l}\text { Arithmetic } \\
\text { mean }\end{array}$ & $\begin{array}{l}\text { Standard } \\
\text { deviation }\end{array}$ \\
\hline \multirow{7}{*}{$\begin{array}{l}\text { How much do you } \\
\text { enjoy life? }\end{array}$} & No answer & 8 & 6.8 & & \\
\hline & Not at all & 2 & 1.7 & & \\
\hline & A little & 6 & 5.1 & & \\
\hline & A moderate amount & 34 & 29.1 & & \\
\hline & Very much & 51 & 43.6 & & \\
\hline & An extreme amount & 16 & 13.7 & & \\
\hline & Total & 117 & 100 & 3.42 & 1.25 \\
\hline \multirow{6}{*}{$\begin{array}{c}\text { To what extent do } \\
\text { you feel your life } \\
\text { to be } \\
\text { meaningful? }\end{array}$} & No answer & 0 & 0 & & \\
\hline & Not at all & 4 & 3.4 & & \\
\hline & A little & 17 & 14.5 & & \\
\hline & A moderate amount & 53 & 45.3 & & \\
\hline & Very much & 43 & 36.8 & & \\
\hline & Total & 117 & 100 & 4.15 & .79 \\
\hline \multirow{6}{*}{$\begin{array}{l}\text { How well are } \\
\text { you able to } \\
\text { concentrate? }\end{array}$} & Not at all & 1 & 0.9 & & \\
\hline & A little & 4 & 3.4 & & \\
\hline & A moderate amount & 25 & 21.4 & & \\
\hline & Very much & 63 & 53.8 & & \\
\hline & Extremely & 24 & 20.5 & & \\
\hline & Total & 117 & 100 & 3.90 & 0.79 \\
\hline \multirow{7}{*}{$\begin{array}{l}\text { How satisfied are } \\
\text { you with yourself? }\end{array}$} & No answer & 1 & 0.9 & & \\
\hline & Very dissatisfied & 1 & 0.9 & & \\
\hline & Dissatisfied & 2 & 1.7 & & \\
\hline & Neither satisfied nor dissatisfied & 22 & 18.8 & & \\
\hline & Satisfied & 66 & 56.4 & & \\
\hline & Very satisfied & 25 & 21.4 & & \\
\hline & Total & 117 & 100 & 3.93 & 0.83 \\
\hline \multirow{7}{*}{$\begin{array}{l}\text { How often do you } \\
\text { have negative } \\
\text { feelings } \\
\text { such as blue mood, } \\
\text { despair, anxiety, } \\
\text { depression? }\end{array}$} & No answer & 4 & 3.4 & & \\
\hline & Never & 2 & 1.7 & & \\
\hline & Seldom & 60 & 51.3 & & \\
\hline & Quite often & 39 & 33.3 & & \\
\hline & Very often & 12 & 10.3 & & \\
\hline & Always & 0 & 0 & & \\
\hline & Total & 117 & 100 & 2.45 & 0.84 \\
\hline
\end{tabular}




\begin{tabular}{|c|c|c|c|c|c|}
\hline & & Number & $\begin{array}{l}\text { Percentage } \\
\text { (\%) }\end{array}$ & $\begin{array}{l}\text { Arithmetic } \\
\text { mean }\end{array}$ & $\begin{array}{l}\text { Standard } \\
\text { deviation }\end{array}$ \\
\hline \multirow{7}{*}{$\begin{array}{l}\text { How satisfied are you } \\
\text { with your personal } \\
\text { relationships? }\end{array}$} & No answer & 1 & 0.9 & & \\
\hline & Very dissatisfied & 0 & 0 & & \\
\hline & Dissatisfied & 4 & 3.4 & & \\
\hline & Neither satisfied nor dissatisfied & 19 & 16.2 & & \\
\hline & Satisfied & 65 & 55.6 & & \\
\hline & Very satisfied & 28 & 23.9 & & \\
\hline & Total & 117 & 100 & 3.97 & 0.82 \\
\hline \multirow{7}{*}{$\begin{array}{l}\text { How satisfied are you } \\
\text { with your sex life? }\end{array}$} & No answer & 5 & 4.3 & & \\
\hline & Very dissatisfied & 4 & 3.4 & & \\
\hline & Dissatisfied & 5 & 4.3 & & \\
\hline & Neither satisfied nor dissatisfied & 33 & 28.2 & & \\
\hline & Satisfied & 42 & 35.9 & & \\
\hline & Very satisfied & 28 & 23.9 & & \\
\hline & Total & 117 & 100 & 3.6 & 1.24 \\
\hline \multirow{7}{*}{$\begin{array}{l}\text { How satisfied are you } \\
\text { with the support you } \\
\text { get from your friends? }\end{array}$} & No answer & 1 & 0.9 & & \\
\hline & Very dissatisfied & 0 & 0 & & \\
\hline & Dissatisfied & 6 & 5.1 & & \\
\hline & Neither satisfied nor dissatisfied & 21 & 17.9 & & \\
\hline & Satisfied & 71 & 60.7 & & \\
\hline & Very satisfied & 18 & 15.4 & & \\
\hline & Total & 117 & 100 & 3.84 & 0.81 \\
\hline
\end{tabular}

Nurses are most dissatisfied with the amount of money they have and the opportunity for recreation, which has been confirmed with the arithmetic means of 3.12 and 3.19. They are most satisfied with the possibility of obtaining good medical care (arithmetic mean 4.00) (Table 5).

\begin{tabular}{|c|c|c|c|c|c|}
\hline & & Number & $\begin{array}{l}\text { Percentage } \\
\text { (\%) }\end{array}$ & $\begin{array}{l}\text { Arithmetic } \\
\text { mean }\end{array}$ & $\begin{array}{l}\text { Standard } \\
\text { deviation }\end{array}$ \\
\hline \multirow{6}{*}{$\begin{array}{l}\text { How safe do you feel in your } \\
\text { daily life? }\end{array}$} & Not at all & 3 & 2.6 & & \\
\hline & A little & 3 & 2.6 & & \\
\hline & A moderate amount & 34 & 29.1 & & \\
\hline & Very much & 55 & 47 & & \\
\hline & Extremely & 22 & 18.8 & & \\
\hline & Total & 117 & 100 & 3.77 & 0.87 \\
\hline \multirow{6}{*}{$\begin{array}{c}\text { How healthy is your physical } \\
\text { environment? }\end{array}$} & Not at all & 5 & 4.3 & & \\
\hline & Slightly & 5 & 4.3 & & \\
\hline & Moderately & 61 & 52.1 & & \\
\hline & Very & 40 & 34.2 & & \\
\hline & Extremely & 6 & 5.1 & & \\
\hline & Total & 117 & 100 & 3.32 & 0.82 \\
\hline
\end{tabular}


Table 5. Environment

\begin{tabular}{|c|c|c|c|c|c|}
\hline & & Number & $\begin{array}{l}\text { Percentage } \\
\text { (\%) }\end{array}$ & $\begin{array}{l}\text { Arithmetic } \\
\text { mean }\end{array}$ & $\begin{array}{l}\text { Standard } \\
\text { deviation }\end{array}$ \\
\hline \multirow{7}{*}{$\begin{array}{l}\text { Have you enough money to } \\
\text { meet your needs? }\end{array}$} & No answer & 2 & 1.7 & & \\
\hline & Not at all & 10 & 8.5 & & \\
\hline & A little & 14 & 12 & & \\
\hline & Moderately & 45 & 38.5 & & \\
\hline & Mostly & 38 & 32.5 & & \\
\hline & Completely & 8 & 6.8 & & \\
\hline & Total & 117 & 100 & 3.12 & 1.10 \\
\hline \multirow{7}{*}{$\begin{array}{l}\text { How available to you is the } \\
\text { information that you need in } \\
\text { your day-to-day life? }\end{array}$} & No answer & 2 & 1.7 & & \\
\hline & Not at all & 1 & 0.9 & & \\
\hline & A little & 3 & 2.6 & & \\
\hline & Moderately & 19 & 16.2 & & \\
\hline & Mostly & 67 & 57.3 & & \\
\hline & Completely & 25 & 21.4 & & \\
\hline & Total & 117 & 100 & 3.91 & 0.91 \\
\hline \multirow{7}{*}{$\begin{array}{l}\text { To what extent do you } \\
\text { have the opportunity for } \\
\text { recreation? }\end{array}$} & No answer & 2 & 1.7 & & \\
\hline & Not at all & 10 & 8.5 & & \\
\hline & A little & 17 & 14.5 & & \\
\hline & Moderately & 40 & 34.2 & & \\
\hline & Mostly & 31 & 26.5 & & \\
\hline & Completely & 17 & 14.5 & & \\
\hline & Total & 117 & 100 & 3.19 & 1.21 \\
\hline \multirow{7}{*}{$\begin{array}{c}\text { How satisfied are you with } \\
\text { the conditions of your living } \\
\text { place? }\end{array}$} & No answer & 1 & 0.9 & & \\
\hline & Very dissatisfied & 1 & 0.9 & & \\
\hline & Dissatisfied & 3 & 2.6 & & \\
\hline & Neither satisfied nor dissatisfied & 24 & 20.5 & & \\
\hline & Satisfied & 51 & 43.6 & & \\
\hline & Very satisfied & 37 & 31.6 & & \\
\hline & Total & 117 & 100 & 4.00 & 0.92 \\
\hline \multirow{7}{*}{$\begin{array}{l}\text { How easily are you able to } \\
\text { get good medical care? }\end{array}$} & No answer & 3 & 2.6 & & \\
\hline & Slightly & 1 & 0.9 & & \\
\hline & Moderately & 7 & 6 & & \\
\hline & Very & 37 & 31.6 & & \\
\hline & Extremely & 49 & 41.9 & & \\
\hline & Not at all & 20 & 17.1 & & \\
\hline & Total & 117 & 100 & 3.61 & 1.03 \\
\hline \multirow{7}{*}{$\begin{array}{c}\text { How satisfied are you with } \\
\text { your transport? }\end{array}$} & No answer & 1 & 0.9 & & \\
\hline & Very dissatisfied & 1 & 0.9 & & \\
\hline & Dissatisfied & 9 & 7.7 & & \\
\hline & Neither satisfied nor dissatisfied & 15 & 12.8 & & \\
\hline & Satisfied & 54 & 46.2 & & \\
\hline & Very satisfied & 37 & 31.6 & & \\
\hline & Total & 117 & 100 & 3.97 & 0.99 \\
\hline
\end{tabular}


Results in all subscales had significant positive correlations. The biggest correlation was observed in the variables mental health and social relations $(p=0.651)$ and in the variable psychological health and environment $(r=0.752)$. Respondents which were more satisfied with social relations assesed their mental health better. Respondents with better mental health were more satisfied with their environment (Table 6).

From table we can see that respondents in age group from 22 to 32 had the best answers in the most of the observed domains. They are most satisfied with the domain "Social relations" with the arithmetic mean of 63.06 and $p$ value 0.048 (Table 7).

\section{Discussion}

Overall, the respondents in this survey gave a pretty good assessment of the overall quality of life. We can conclude that the respondents' self-assessment area quality of life and health satisfaction gave an average grade of 3.74 .

One of the studies showed that the most important indicator of the quality of life is satisfaction with personal achievements (7). A survey conducted in Croatia on 1048 respondents showed that general satisfaction with life is significantly associated with the satisfaction with health (7). Australian psychologist Cummins in a systematic review of the literature in the area of Western Europe, North America and Australia analyzed the distribution of self-assessment of life satisfaction of the adult population and concluded that the average life satisfaction level of $75 \% \pm$ scale maximum. This indicates the high level of satisfaction (8). The WHO study shows that the impact of mental disorders on quality of life equals to or is even greater than the impact of chronic diseases, such as arthritis, diabetes, heart, lung and neurological diseases. Personality is also one of the most important indicators of quality of life $(5,6)$.

In this study, a significant positive indicator is young age. The assumption was that younger nurses have better social relations. Research has shown that social interaction reduces with age (9). This research showed that people who are between 22 and 32 years old give much higher grades than older people. According to groups, younger people are significantly more satisfied with social relations.

In the domain of "Physical health" respondents were most satisfied with the possibility of moving around and their ability to work. The average grade for the domain mental health is very good. Respondents were most satisfied with the meaning of their own

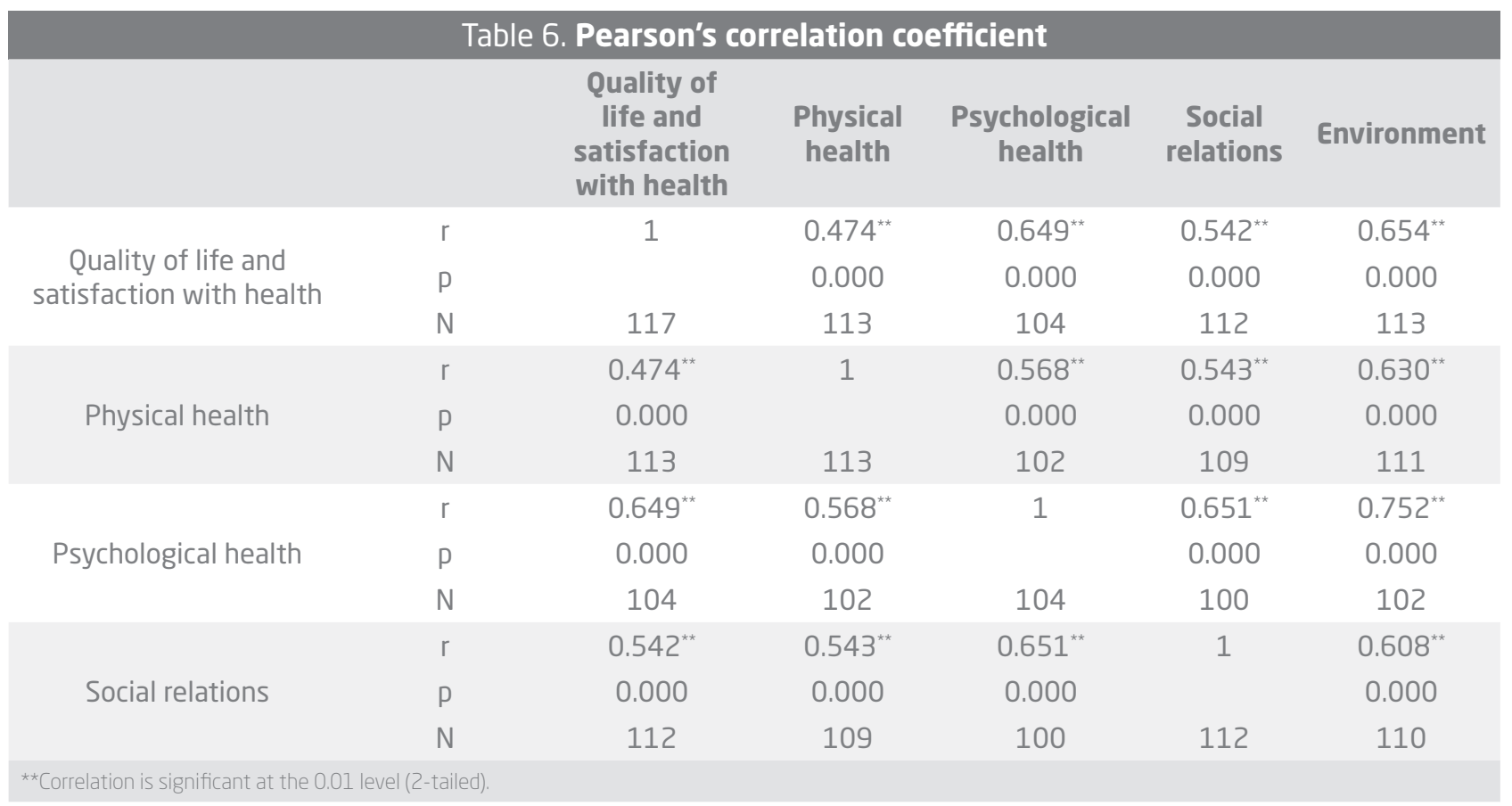


Table 7. Testing the significance of differences in the observed domains according to age categories

\begin{tabular}{|c|c|c|c|c|}
\hline & Age categories & $\mathbf{N}$ & $\begin{array}{l}\text { Arithmetic } \\
\text { mean of } \\
\text { ranks }\end{array}$ & $p$ value \\
\hline \multirow{5}{*}{ Quality of life and satisfaction with health } & $22-32$ & 36 & 62.47 & \multirow{5}{*}{0.361} \\
\hline & $33-43$ & 29 & 51.72 & \\
\hline & $44-54$ & 28 & 50.27 & \\
\hline & 55 and more & 18 & 58.86 & \\
\hline & Total & 111 & & \\
\hline \multirow{5}{*}{ Physical health } & $22-32$ & 35 & 53.19 & \multirow{5}{*}{0.387} \\
\hline & $33-43$ & 28 & 46.66 & \\
\hline & $44-54$ & 26 & 58.02 & \\
\hline & 55 and more & 18 & 61.19 & \\
\hline & Total & 107 & & \\
\hline \multirow{5}{*}{ Psychological health } & $22-32$ & 34 & 57.03 & \multirow{5}{*}{0.072} \\
\hline & $33-43$ & 26 & 48.19 & \\
\hline & $44-54$ & 23 & 37.80 & \\
\hline & 55 and more & 16 & 55.53 & \\
\hline & Total & 99 & & \\
\hline \multirow{5}{*}{ Social relations } & $22-32$ & 33 & 63.06 & \multirow{5}{*}{0.048} \\
\hline & $33-43$ & 29 & 54.24 & \\
\hline & $44-54$ & 27 & 41.15 & \\
\hline & 55 and more & 18 & 56.28 & \\
\hline & Total & 107 & & \\
\hline \multirow{5}{*}{ Environment } & $22-32$ & 35 & 54.03 & \multirow{5}{*}{0.420} \\
\hline & $33-43$ & 28 & 50.27 & \\
\hline & $44-54$ & 26 & 50.65 & \\
\hline & 55 and more & 18 & 64.58 & \\
\hline & Total & 107 & & \\
\hline
\end{tabular}

life. Respondents were very satisfied with all three aspects in "Social relationship" domain, relationship with loved ones, sex life and support from friends.

In the area "Environment" the respondents are satisfied with the housing conditions. Respondents were least satisfied with the financial situation and opportunities for recreation. Most of the nurses said that they are not involved in regular exercise because they do not have time, are tired or do not have access to sports facilities. Other research recommends organizing team-building to live a healthy lifestyle (10).

When examining relations between the observed attitudes of respondents it can be concluded that there is a significant correlation between satisfaction with environment and mental health and that there is also a correlation between satisfaction with mental health and social relationships.

The study relied on self-assessment of the quality of life of nurses, which could lead to subjective results. Further research in this area should take into account the objective methods, such as medical records, to determine the physical health. Nursing requires accuracy, precision, warmth, responsibility and the highest professionalism and expertise, and to do all the necessary interventions to carry out further research on the impact of shift work, work in shifts at their both professional and personal life. This study is only a small contribution to that. 


\section{Conclusion}

According to the results of the conducted research it can be concluded:

- Quality of life of nurses is at a good level

- Most of the nurses are satisfied with their health

- Younger nurses are more satisfied with social relationships.

- Respondents are most satisfied with their own agility and meaning of their lives, while they are most dissatisfied with their financial situation and opportunities for recreation.

\section{References}

1. Henderson V. Osnovna načela zdravstvene njege. Prvo izdanje. Zagreb: HUSE i HUMS; 1994. Croatian.

2. Čorić O, Ljubotina D. Kvaliteta života ratnih veterana s tjelesnim invaliditetom koji igraju sjedeći odbojku. Ljetopis socijalnog rada. 2013;20:387-414. Croatian. Available from: https://hrcak.srce.hr/file/175116

3. Cummins RA. Quality of life definition and terminology: a discussion document from the International Society for Quality of life Studies. International Society for Quality of life Studies. 1998;1-43. Available from: http:// www.isqols.org/wp-content/uploads/2012/10/1__ _ Quality-of-Life-Definition-and-Terminology-A-Discussion-Document-from-the-International-Society-forQuality-of-Life-Studies-1998.pdf

4. Vuletić G, Misajon RA. Subjektivna kvaliteta života. U: Vuletić G, ur. Kvaliteta života i zdravlje. Osijek: Filozofski fakultet Sveučilišta u Osijeku. 2011:9-16. Croatian. Available from: https://bib.irb.hr/datoteka/592441. KVALITETA_IVOTA_I_ZDRAVLJE.pdf

5. World Health Organization. The World Health report 1997. Available from: www.who.int/whr/1997/en/

6. Development of the World Health Organization WHOQOLBREF quality of life assessment. The WHOQOL Group. Psychol Med. 1998;28:551-8.

7. Kaliterna Lipovčan LJ, Prizmić Larsen Z, Brkljačić T. Međunarodni indeks dobrobiti - podaci za Hrvatsku. U: Vuletić G, ur. Kvaliteta života i zdravlje. Osijek: Filozofski fakultet Sveučilišta u Osijeku. 2011:41-51. Croatian. Available from: http://www.ijf.hr/Eu4/kaliternaprizmic.pdf

8. Cummins RA. Normative life satisfaction: measurement issues and a homeostatic model. Soc Indic Res. 2003;53:225-56. Available from: https://link.springer. com/article/10.1023/A:1024712527648

9. Sorić M, Golubić R, Milošević M, Juras K, Mustajbegović J. Shift Work, Quality of Life and Work Ability among Croatian hospital nurses. Coll Antropol. 2013;2:37984. Available from: https://www.ncbi.nlm.nih.gov/ pubmed/23940978

10. Shao MF, Chou YC, Yeh MY, Tzeng WC. Sleep quality and quality of life in female shift-working nurses. J Adv Nurs. 2010;7:1565-72. Available from: https:// www.ncbi.nlm.nih.gov/pubmed/20492021 


\section{KVALITETA ŽIVOTA MEDICINSKIH SESTARA U OSIJEKU}

\section{Sažetak}

Uvod. Medicinska je sestra ta koja će biti uz pacijenta, poslušati ga, razgovarati, pružiti osjećaj sigurnosti i usmjeravati svu svoju pažnju na njega. Medicinska je sestra jedinstvena. Svjetska zdravstvena organizacija definirala je kvalitetu života kao percepciju uloge pojedinca u kontekstu kulture i vrijednosti u kojima živi te u odnosu na njegove ciljeve, očekivanja, standarde i brige.

Cilj. Ispitati kvalitetu života medicinskih sestara u Kliničkom bolničkom centru Osijek i Domu zdravlja Osijek.

Nacrt studije. Presječna studija.

Metode. U ispitivanje je bilo uključeno ukupno 117 medicinskih sestara/tehničara, od čega je 64 ispitanika bilo iz Kliničkog bolničkog centra (KBC) Osijek, a 53 iz primarne zdravstvene zaštite Doma zdravlja Osijek. $U$ istraživanju se kao instrument ispitivanja primijenio anketni upitnik Anketa svjetske zdravstvene organizacije o kvaliteti života.

Rezultati. Medicinske sestre ocijenile su svoju kvalitetu života dobrom (45,3\%), a također su zadovoljne i svojim zdravljem (59,8 \%). Ispitanici u dobnoj skupini od 22 do 32 najzadovoljniji su domenom „Socijalni odnosi" s aritmetičkom sredinom od 63,06 uz vrijednost $p=0,048$. Sva tri pitanja iz domene "Socijalni odnosi” imala su visoku aritmetičku sredinu, koja je iznosila više od 3,60.

Zaključak. Kvaliteta života medicinskih sestara na dobroj je razini. Mlađi ispitanici imaju bolju kvalitetu života. Ispitanici su najzadovoljniji vlastitom agilnošću i značenjem svojih života, dok su najnezadovoljniji financijskom situacijom i mogućnostima za rekreaciju. 